\title{
Optimasi Prediksi Penyakit Systemic Lupus Erythematosus Menggunakan Algoritma Particle Swarm Optimization

\author{
Optimization of Systemic Lupus Erythematosus Prediction using Particle Swarm
} Optimization Algorithm
}

\author{
Ramalia Noratama Putri ${ }^{1}$, Debi Setiawan ${ }^{2}$ \\ ${ }^{1}$ Sistem Informasi, Sekolah Tinggi Ilmu Komputer Pelita Indonesia \\ ${ }^{2}$ Teknik Informatika, STMIK Amik Riau \\ E-mail: ${ }^{1}$ ramalianoratamaputri@lecturer.pelitaindonesia.ac.id, ${ }^{2}$ debisetiawan@stmik-amik- \\ riau.ac.id
}

\begin{abstract}
Abstrak
Systemic lupus erythematosus (SLE) juga dikenal sebagai lupus, adalah penyakit autoimun di mana sistem kekebalan tubuh secara keliru menyerang jaringan sehat di banyak bagian tubuh. Jumlah penderita SLE semakin meningkat tiap tahun. Systemic Lupus Erythematosus telah diderita sebanyak lima juta orang diseluruh dunia. Penderita SLE di China lebih tinggi dari negara Eropa dan Amerika Utara, perkiraan prevalensi SLE adalah 50-100 kasus per 100.000 orang. Sedangkan di Indonesia, berdasarkan Sistem Informasi Rumah Sakit Online (SIRS Online) pada tahun 2014 terdapat 1.169 penderita SLE, tahun 2015 terdapat 1.336 penderita SLE, dan tahun 2016 terdapat 2.116, dari data tersebut terlihat peningkatan angka penderita SLE setiap tahun. Salah satu penyebab dari tingginya angka penderita penyakit SLE adalah sulitnya mendiagnosa penyakit SLE. Tantangan terbesar dalam ilmu kedokteran adalah bagaimana melakukan deteksi dini dalam mendiagnosa penyakit SLE. Deteksi dini dalam diagnosa penyakit SLE dapat dilakukan dengan prediksi penyakit SLE. Penelitian ini melakukan optimasi terhadap hasil prediksi penyakit SLE dengan metode genetika. Metode optimasi yang digunakan adalah algoritma particle swarm optimization. Hasil dari penelitian adalah algoritma particle swarm optimization dapat melakukan optimasi dengan 6 pasien teridentifikasi secara tepat. Akurasi dari optimasi adalah $88 \%$.
\end{abstract}

Kata kunci: prediksi, Systemic lupus Erythematosus, genetika, algoritma particle swarm optimization

\begin{abstract}
Systemic lupus erythematosus (SLE), also known as lupus, is an autoimmune disease in which the immune system mistakenly attacks healthy tissue in many parts of the body. The number of SLE sufferers is increasing every year. Systemic Lupus Erythematosus has suffered as many as five million people worldwide. People with SLE in China are higher than European countries and North America, the estimated prevalence of SLE is 50-100 cases per 100,000 people. While in Indonesia, based on the Online Hospital Information System (SIRS Online) in 2014 there were 1,169 SLE sufferers, in 2015 there were 1,336 SLE sufferers, and in 2016 there were 2,116 , from the data it was seen an increase in the number of SLE sufferers every year. One of the causes of the high number of people with SLE is the difficulty of diagnosing SLE. The biggest challenge in medical science is how to do early detection in diagnosing SLE. Early detection in the diagnosis of SLE can be done by predicting SLE. This research optimizes the prediction results of SLE by genetic methods. The optimization method used is the particle swarm optimization algorithm. The results of the study are the particle swarm optimization algorithm can optimize with 6 patients correctly identified. The accuracy of the optimization is $88 \%$.
\end{abstract}


Keywords: prediction, Systemic lupus Erythematosus, genetics, particle swarm optimization algorithm

\section{PENDAHULUAN}

Systemic Lupus Erythematosus (SLE) juga dikenal sebagai lupus, adalah penyakit autoimun di mana sistem kekebalan tubuh secara keliru menyerang jaringan sehat di banyak bagian tubuh. Bagian tubuh yang diserang yaitu kulit, sendi, jantung, paru-paru, ginjal, paru, dan organ dalam lainnya.[1].

Jumlah penderita SLE semakin meningkat tiap tahun. Systemic Lupus Erythematosus telah diderita sebanyak lima juta orang diseluruh dunia[2]. Penderita SLE di China lebih tinggi dari negara Eropa dan Amerika Utara, perkiraan prevalensi SLE adalah 50-100 kasus per 100.000 orang [3]. Sedangkan di Indonesia, berdasarkan Sistem Informasi Rumah Sakit Online (SIRS Online) pada tahun 2014 terdapat 1.169 penderita SLE, tahun 2015 terdapat 1.336 penderita SLE, dan tahun 2016 terdapat 2.116, dari data tersebut terlihat peningkatan angka penderita SLE setiap tahun[4]. Salah satu penyebab dari tingginya angka penderita penyakit SLE adalah sulitnya mendiagnosa penyakit SLE. SLE dikenal dengan penyakit seribu wajah yang memiliki gambaran klinis yang luas dan riwayat penyakit yang beragam. Sehingga menyebabkan keterlambatan diagnosis[4].

Tantangan terbesar dalam ilmu kedokteran adalah bagaimana melakukan deteksi dini dalam mendiagnosa penyakit SLE[5]. Deteksi dini dalam diagnosa penyakit SLE dapat dilakukan dengan prediksi penyakit SLE. Banyak peneliti terdahulu yang sudah melakukan penelitian tentang prediksi penyakit SLE dengan menggunakan metode yang berbeda-beda yaitu, peneliti sebelumnya menggunakan metode Natural Language Processing (NLP) untuk memprediksi penyakit SLE, hasil penelitian terbsebut mendapatkan akurasi $86 \%$ [6]. Penerapan Recurrent Neural Networks (RNNs) sebagai model pembelajaran mesin untuk memprediksi kerusakan Kronis pada pasien SLE menghasilkan akurasi 77\%[7].

Pada penelitian sebelumnya penulis sudah menerapkan metode backpropagation [8] dan genetika [9] dalam memprediksi penyakit Autoimun. Perbandingan akurasi pada penerapan metode backpropagation dan genetika adalah $83 \%$ dan $76 \%$ [10], dari hasil penelitian tersebut metode backpropagation lebih baik melakukan prediksi dari genetika. Pada penelitian ini penulis menerapkan optimasi menggunakan algoritma Particle Swarm Optimization untuk meningkatkan prediksi penyakit SLE hasil dari metode genetika.

Penerapan algoritma PSO untuk optimasi telah banyak dilakukan oleh peneliti sebelumnya, yaitu optimasi pemenuhan gizi balita, hasil penelitian tersebut algoritma PSO sangat berpengaruh terhadap pemenuhan gizi balita dan menghemat pengeluaran orang tua balita sebesar 25\%[11], dan optimasi parameter SPA dengan PSO sehingga menemukan parameter SPA yang optimal pada enam kombinsai virus dangue[12]. Oleh karena itu peneliti menggunakan PSO untuk optimasi hasil prediksi algoritma genetika. Sehingga hasil prediksi penyakit SLE lebih tepat.

\section{METODE PENELITIAN}

\subsection{Tahapan Penelitian}

Tahapan dalam menyelesaikan masalah pada penelitian ini dapat dilihat pada gambar berikut ini :

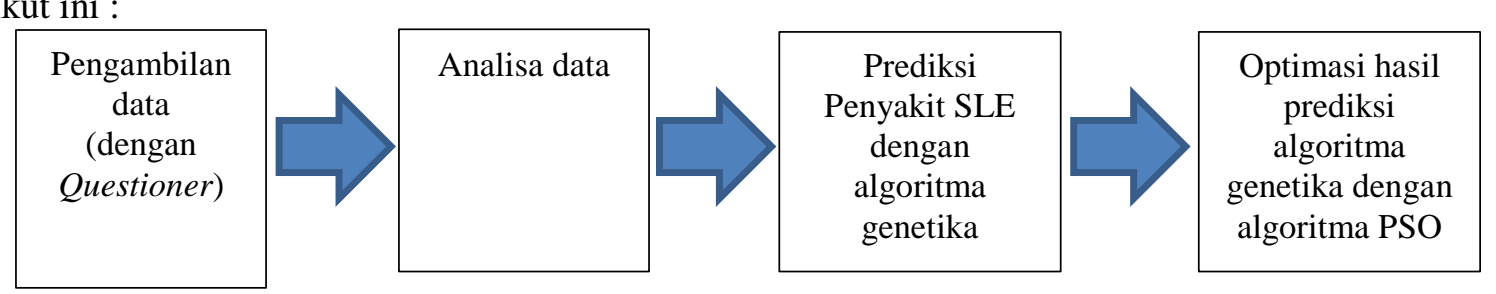

Gambar 1 Tahapan Penelitian 
Pengambilan data pada penelitian ini dilakukan dengan memberikan questioner pada pasien penyakit dalam di Rumah Sakit Arifin Achmad Pekanbaru, Riau. Questioner berisikan daftar pertanyaan yang mewakili variable dari penyakit SLE. berikut daftar pertanyaan pada questioner :

Tabel 1 Daftar Pertanyaan pada Questioner

\begin{tabular}{|l|l|}
\hline No. & \multicolumn{1}{|c|}{ Daftar Pertanyaan } \\
\hline 1 & Apakah bapak/ibu merasakan sariawan berulang dalam dua atau tiga minggu ini ? \\
\hline 2 & Apakah bapak atau ibu merasakan demam yang tidak diketahui penyebabnya ? \\
\hline 3 & Apakah bapak/ibu mengidap hipertensi atau tekanan darah tinggi dalam seminggu ini ? \\
\hline 4 & $\begin{array}{l}\text { Apakah bapak/ibu mengalami limfadenopati, atau disebut juga pembekan kelenjer getah bening, contoh } \\
\text { ada bengkak pada ketiak, dagu belakang telinga, leher pangkal, paha belakang kepala ? }\end{array}$ \\
\hline 5 & Apakah bapak/ibu mengalami sakit kepala hebat dalam minggu ini ? \\
\hline 6 & Apakah bapak/ibu mengalami migraine ? \\
\hline 7 & Apakah bapak/ibu mengalami rambut rontok ? \\
\hline 8 & $\begin{array}{l}\text { Apakah bapak/ibu mengalami mata kering dalam beberapa waktu ini, dan mewajibkan bapak ibu } \\
\text { menggunakan obat tetes mata ? }\end{array}$ \\
\hline 9 & Apakah bapak ibu dalam beberapa hari ini agak depresi ? \\
\hline 10 & Apakah bapak/ibu mengalami nyeri pada dada? \\
\hline 11 & Apakah bapak/ibu mengalami hilang ingatan ? \\
\hline 13 & Apakah bapak/ibu napas pendek akibat anemia, inflamasi paru-paru atau jantung ? \\
\hline 14 & $\begin{array}{l}\text { Apakah ada tanda retensi dan akumulasi cairan tubuh, terjadi pembengkakan pada pergelangan kaki ? } \\
\text { dingin atau karena stres (fenomena Raynaud) ? }\end{array}$ \\
\hline
\end{tabular}

\subsection{Algoritma Particle Swarm Optimization}

Algoritma PSO pertama kali dikenalkan oleh J. Kennedy tahun 1995 [13]. PSO merupakan salah satu metode metaheuristic yang pencarian solusi berdasarkan populasi dari sekelompok burung atau ikan, dimana setiap populasi memiliki individu yang dapat mempengaruhi individu lainya[14].

Untuk menemukan solusi yang optimal, masing-masing partikel bergerak kearah posisi yang terbaik sebelumnya dan posisi terbaik secara global. Sebagai contoh, partikel ke-i dinyatakan sebagai: $x i=(x i 1, x i 2, \ldots . . x i d)$ dalam ruang d-dimensi. Posisi terbaik sebelumnya dari partikel ke-i disimpan dan dinyatakan sebagai pbesti $=($ pbesti, 1, pbesti,2,...pbesti,d $)$. Indeks partikel terbaik diantara semua partikel dalam kawanan group dinyatakan sebagai gbestd. Kecepatan partikel dinyatakan sebagai: $v i=(v i, 1, v i, 2, \ldots . v i, d)$ [15]. Tahapan PSO dapat dijabarkan sebagai berikut :

1. Asumsikan bahwa ukuran kelompok atau kawanan (jumlah partikel) adalah $\mathrm{N}$

2. Tentukan nilai R1-R2 (Nilai Random) yang diasumsikan sendiri, untuk literasi pertama

3. Hitung kecepatan partikel j pada iterasi ke i dengan rumus sebagai berikut :

$v j(i)=v j(i-1)+c 1 r 1[$ Pbest,$j-x j(i-1)]+(6) c 2 r 2[$ Gbest $-x j(i-1)], j=1,2, \ldots, N$

dimana c1 dan c2 masing-masing adalah learning rates untuk kemampuan individu (cognitive) dan pengaruh sosial (kawanan), dan $\mathrm{r} 1$ dan $\mathrm{r} 2$ bilangan random yang berdistribusi uniforml dalam interval 0 dan 1 . Jadi parameter $\mathrm{c} 1$ dan $\mathrm{c} 2$ menunjukkan bobot dari memory (position) sebuah partikel terhadap memory (posisi) dari kelompok (swarm). Nilai dari c1 dan c2 biasanya adalah 2 sehingga perkalian c1r1 dan c2r2 memastikan bahwa partikel-partikel akan mendekati target sekitar setengah selisihnya.

4. Hitung $\mathrm{x}$ baru dengan cara mengurangkan $\mathrm{v}$ lama dengan $\mathrm{x}$ lama.

5. Cek apakah solusi yang sekarang sudah konvergen. Jika posisi semua partikel menuju ke satu nilai yang sama, maka ini disebut konvergen. Jika belum konvergen maka langkah 4 diulang dengan memperbarui iterasi $\mathrm{i}=\mathrm{i}+1$, dengan cara menghitung nilai baru dari Pbest, $\mathrm{j}$ dan Gbest. 
Proses iterasi ini dilanjutkan sampai semua partikel menuju ke satu titik solusi yang sama. Biasanya akan ditentukan dengan kriteria penghentian (stopping criteria), misalnya jumlah selisih solusi sekarang dengan solusi sebelumnya sudah sangat kecil.

\subsection{Evaluasi Optimasi PSO}

Untuk mengukur pengoptimalan hasil prediksi penyakit SLE dapat dilihat dari hasil akurasi yang diukur menggunakan confusion matrix. Confusion Matrix merupakan evaluasi kinerja dari model klasifikasi berdasarkan objek dengan memperkirakan yang benar atau salah[16]. Akurasi bertujuan untuk mengetahui keakuratan prediksi jumlah pasien teridentifikasi penyakit SLE yang benar.

$$
\text { Accuracy }=\frac{T P+T N}{T P+T N+F P+F N}
$$

\section{Keterangan :}

1. True Positive (TP) : proporsi positif yang terdapat dalam data set yang diklasifikasikan positif.

2. False Negative (FN) : proporsi negatif yang terdapat dalam data set yang diklasifikasikan negatif.

3. False Positive (FP) : proporsi negatif yang terdapat dalam data set yang diklasifikasikan positif.

4. True Negatif $(\mathrm{TN})$ : proporsi positif yang terdapat dalam data set yang diklasifikasikan negatif.

\section{HASIL DAN PEMBAHASAN}

\subsection{Hasil Prediksi dengan Algoritma Genetika}

Pada penelitian sebelumnya yaitu prediksi penyakit SLE menggunakan metode genetika didapatkan hasil seperti tabel berikut ini :

Tabel 2 Hasil Prediksi Penyakit SLE dengan Metode Genetika

\begin{tabular}{|l|l|c|}
\hline \multicolumn{2}{|c|}{ Prediksi } \\
\hline C1-13 & Otak & 6 \\
\hline & Ginjal & 4 \\
\hline & Kulit & 1 \\
\hline & Tidak Sakit & 6 \\
\hline C14-30 & Otak & 3 \\
\hline & Ginjal & 2 \\
\hline & Kulit & 0 \\
\hline & Tidak Sakit & 8 \\
\hline \multicolumn{2}{|l|}{ Total Questioner } & 30 \\
\hline
\end{tabular}

Penyakit SLE dapat menyebabkan inflamasi atau kerusakan pada bagian tubuh seperti persendian, kulit, ginjal, jantung, paru-paru, pembuluh dara, dan otak[2]. Hasil prediksi menggunakan genetika didapat 16 pasien yang terindentifikasi penyakit SLE dengan rincian, SLE yang menyebabkan kerusakan pada otak 9 pasien, ginjal 6 pasien, dan kulit 1 pasien.

\subsection{Tahapan Optimasi dengan Algoritma Particle Swarm Optimization}

1. Menentukan bahwa ukuran kelompok atau kawanan (jumlah partikel) adalah $\mathrm{N}$, pada kasus ini $\mathrm{N}=3$, yaitu X1 untuk kelempok pasien yang terindikasi SLE yang menyerang bagian otak, $\mathrm{X} 2$ kelempok pasien yang terindikasi SLE yang menyerang bagian ginjal, X3 kelempok pasien yang terindikasi SLE yang menyerang bagian kulit. 
Tabel 3 Kelompok Jumlah Partikel

\begin{tabular}{|c|c|c|}
\hline $\begin{array}{c}\text { XI } \\
\text { Otak }\end{array}$ & $\begin{array}{c}\text { X2 } \\
\text { Ginjal }\end{array}$ & $\begin{array}{c}\text { X3 } \\
\text { Kulit }\end{array}$ \\
\hline 56.98 & & \\
\hline & 21.28 & \\
\hline & 28.42 & \\
\hline & 28.42 & \\
\hline & 14.14 & \\
\hline 71.26 & & \\
\hline 71.26 & & \\
\hline 56.98 & & \\
\hline 142.66 & & \\
\hline 356.86 & & \\
\hline & & 35.56 \\
\hline
\end{tabular}

2. Tentukan nilai R1-R2 (Nilai Random) yang diasumsikan sendiri, untuk literasi pertama nilai random adalah $\mathrm{R} 1=0.4$ dan $\mathrm{R} 2=0.5$

3. Hitung kecepatan partikel $\mathrm{j}$ pada iterasi ke i dengan rumus sebagai berikut :

$$
\begin{aligned}
& v j(i)=v j(i-1)+c 1 r 1[\text { Pbest }, j-x j(i-1)]+(6) c 2 r 2[\text { Gbest }-x j(i-1)] \\
& \text { Diperoleh : } \\
& \mathrm{V} 1=0+0.4 *(56.98-56.98)+0.5^{*}(356,86-56.98)=149.94
\end{aligned}
$$

Lanjutkan langkah ke 3 sampai langkah ke V1,V2...Vn

Tabel 4 Iterasi 1 Optimasi dengan Metode PSO

\begin{tabular}{|l|l|l|}
\hline $\mathbf{V 1}$ & $\mathbf{V 2}$ & $\mathbf{V 3}$ \\
\hline 149.94 & & \\
\hline & 3.57 & \\
\hline & 0.00 & \\
\hline & 0.00 & \\
\hline & 7.14 & \\
\hline 142.80 & & \\
\hline 142.80 & & \\
\hline 149.94 & & \\
\hline 107.10 & & \\
\hline 0.00 & & \\
\hline & & 0.000 \\
\hline
\end{tabular}

4. Hitung $\mathrm{x}$ baru dengan cara mengurangkan $\mathrm{v}$ lama dengan $\mathrm{x}$ lama.

$$
\begin{aligned}
& \mathrm{X} 1(\text { baru })=\mathrm{V} 1(\text { awal })-\mathrm{X} 1(\text { awal }) \\
& \mathrm{X} 1(\text { baru })=149.94-56.98=206.92
\end{aligned}
$$

Tabel 5 Populasi X baru

\begin{tabular}{|c|c|c|}
\hline $\mathbf{X 1}$ & $\mathbf{X 2}$ & $\mathbf{X 3}$ \\
\hline 206.92 & & \\
\hline & 24.85 & \\
\hline & 28.42 & \\
\hline & 28.42 & \\
\hline & 21.28 & \\
\hline 214.06 & & \\
\hline 214.06 & & \\
\hline 206.92 & & \\
\hline
\end{tabular}




\begin{tabular}{|l|l|l|}
\hline 249.76 & & \\
\hline 356.86 & & \\
\hline & & 35.56 \\
\hline
\end{tabular}

\section{Nilai Konvergen}

Konvergen adalah selisih nilai $\mathrm{x}$ saling dekat, jika masih belum saling dekat maka lakukan sampai iterasi ke $n$, pada iterasi pertama populasi yang didapatkan dapat dilihat pada tabel 6. Karena selisih konvergen belum saling dekat maka lakukan kembali 1 sampai 4.

Tabel 6 Nilai selisih X

\begin{tabular}{|c|c|c|}
\hline XI & $\mathbf{X} 2$ & $\mathbf{X 3}$ \\
\hline Otak & Ginjal & Kulit \\
\hline \multicolumn{3}{|l|}{206.92} \\
\hline & 24.85 & \\
\hline & 28.42 & \\
\hline & 28.42 & \\
\hline & 21.28 & \\
\hline \multicolumn{3}{|l|}{214.06} \\
\hline \multicolumn{3}{|l|}{214.06} \\
\hline \multicolumn{3}{|l|}{206.92} \\
\hline \multicolumn{3}{|l|}{249.76} \\
\hline \multicolumn{3}{|l|}{356.86} \\
\hline & & 35.56 \\
\hline XI & X2 & X3 \\
\hline Otak & Ginjal & Kulit \\
\hline \multicolumn{3}{|l|}{71.26} \\
\hline \multicolumn{3}{|l|}{78.40} \\
\hline & 21.28 & \\
\hline & 21.28 & \\
\hline 85.54 & & \\
\hline
\end{tabular}

Pada tabel 2 iterasi 1 optimasi dengan PSO selisih konvergen yaitu selesih angka yang saling dekat masih belum mendekati, maka dialakukan iterasi ke-n sampai selisih angka saling dekat.

Tabel 7 Iterasi 2 Optimasi dengan Metode PSO
\begin{tabular}{|l|l|l|l|l|l|}
\hline \multicolumn{1}{|c|}{ V1 } & V2 & V3 & X1 & X2 & X3 \\
\hline 104.96 & & & 311.88 & & \\
\hline & 2.50 & & & 27.35 & \\
\hline & 0.00 & & & 28.42 & \\
\hline & 0.00 & & & 28.42 & \\
\hline & 5.00 & & & 26.26 & \\
\hline 99.96 & & & 314.02 & & \\
\hline 99.96 & & & 314.02 & & \\
\hline 104.96 & & & 311.88 & & \\
\hline 74.97 & & & 324.73 & & \\
\hline 0.00 & & & 356.86 & & \\
\hline & & 0.000 & & & 35.56 \\
\hline $\mathrm{V} 1$ & $\mathrm{~V} 2$ & $\mathrm{~V} 3$ & $\mathrm{X} 1$ & $\mathrm{X} 2$ & $\mathrm{X} 3$ \\
\hline 10.00 & & & 81.25 & & \\
\hline 5.00 & & & 83.40 & & \\
\hline & 0.00 & & & 21.28 & \\
\hline & 0.00 & & & 21.28 & \\
\hline 0.00 & & & 85.54 & & \\
\hline
\end{tabular}

Pada iterasi kedua selesih angka saling dekat sudah mendekati, maka pada iterasi ke 2 didapatkan pengoptimalan prediksi penyakit SLE. 


\subsection{Evaluasi Optimasi PSO}

Evaluasi Optimasi PSO dilakukan untuk mengatahui nilai akurasi prediksi jumlah pasien yang terindikasi penyakit SLE setelah diterapkan algoritma PSO, berikut nilai akurasi :

\section{Algoritma Genetika}

$$
\begin{aligned}
\text { Accuracy } & =\frac{114.24+100}{114.24+100+14+16} \\
& =0.88 \times 100 \\
& =88 \%
\end{aligned}
$$

\section{Algoritma PSO}

$$
\begin{aligned}
\text { Accuracy } & =\frac{42,84+100}{42.84+100+14+6} \\
& =0.88 \times 100 \\
& =88 \%
\end{aligned}
$$

\section{KESIMPULAN DAN SARAN}

Akurasi dari hasil prediksi dengan genetika adalah $88 \%$, setelah dilakukan optimalisai menggunakan algortima PSO nilai akurasi tetap 88\%. Namun, hasil prediksi dengan optimalisasi menjadi lebih baik, pada prediksi menggunakan genetika terdapat 16 pasien yang diprediksi menderita penyakit SLE, setelah dilakukan optimalisasi menggunakan PSO jumlah pasien yang diprediksi menderita penyakit SLE menjadi 6 pasien dengan nilai konvergen yang saling dekat.

Tabel 8 Hasil Prediksi Penyakit SLE denga Optimasi PSO

\begin{tabular}{|l|l|r|}
\hline \multicolumn{2}{||}{ PREDIKSI } \\
\hline C1-13 & Otak & \\
\hline & Ginjal & 2 \\
\hline & Kulit & 1 \\
\hline & Tidak Sakit & 14 \\
\hline & & \\
\hline C14-30 & Otak & 1 \\
\hline & Ginjal & 2 \\
\hline & Kulit & 0 \\
\hline & Tidak Sakit & 10 \\
\hline Total Questioner & & 30 \\
\hline
\end{tabular}

Hal ini membuktikan bahwa nilai PSO lebih stabil dari genetika[17]. Untuk penelitian selanjutnya agar nilai optimasliasi lebih optimal perlu dilakukan modifikasi pada PSO.

\section{UCAPAN TERIMA KASIH}

Terima kasih disampaikan pada Kementrian Riset Teknologi dan Pendidikan Tinggi atas dana Penelitian Dosen Pemula tahun 2019. 


\section{DAFTAR PUSTAKA}

[1] S. Waluyo and B. Marhendra, Penyakit-Penyakit Autoimun. Jakarta: Gramedia, 2014.

[2] N. Putu, W. Purnama, F. Keperawatan, U. Katolik, W. Mandala, and S. Telp, "Faktor Pencetus Gejala Dan Perilaku Pencegahan Systemic Lupus Erythematosus ( Precipitating Factors and Preventive Behavior towards the Exposures of Systemic Lupus Erythematosus )," J. Ners, vol. 11, no. 1, pp. 213-219, 2014.

[3] L. Mu, "Mortality And Prognostic Factors In Chinese Patients With Systemic Lupus Erythematosus," pp. 1-11, 2018.

[4] Kemenkes RI, Situasi Lupus Indonesia. Jakarta: Pusat Data dan Informasi Kementrian kesehatan, 2017.

[5] R. Felten et al., "10 Most Important Contemporary Challenges In The Management Of SLE," pp. 1-6, 2019.

[6] T. Li, L. Jiang, L. Wang, and H. Xu, "Artificial Intelligence Predict The Lupus Nephritis Based On Full-Phenotype Database With Natural Language Processing Technology," Lupus Sci. Med., vol. 2, no. table 1, pp. 212-213, 2019.

[7] F. Ceccarelli et al., "Prediction Of Chronic Damage In Systemic Lupus Erythematosus By Using Machine- Learning Models," vol. 35, pp. 1-13, 2017.

[8] D. Setiawan and R. N. Putri, "Prediction of Autoimmune Disease Using Backpropagation Method," Pros. CELSciTech 3, vol. 3, pp. 52-60, 2018.

[9] D. Setiawan, R. N. Putri, and R. Suryanita, "Implementasi Algoritma Genetika Untuk Prediksi Penyakit Autoimun," RABIT (Jurnal Teknol. dan Sist. Inf. Univrab), vol. 4, no. 1, pp. 8-16, 2019.

[10] D. Setiawan, R. N. Putri, and R. Suryanita, "Perbandingan Algoritma Genetika dan Backpropagation pada Aplikasi Prediksi Penyakit Autoimun," khazanah Inform., vol. 5, no. 1, pp. 21-27, 2019.

[11] L. Istikomah and I. Cholissodin, "Implementasi Algoritma Particle Swarm Optimization ( PSO ) untuk Optimasi Pemenuhan Kebutuhan Gizi Balita," J. Pengemb. Teknol. Inf. dan Ilmu Komput., vol. 1, no. 11, 2017.

[12] D. Rahmalia, A. Romatullah, and M. S. Pradana, "Estimasi Parameter Super Pairwise Alignment pada Kombinasi Virus Dengue Menggunakan Particle Swarm Optimization," Techno.COM, vol. 18, no. 3, pp. 264-274, 2019.

[13] J. Kennedy and R. Eberhart, "Particle Swarm Optimization," IEEE, pp. 1942-1948, 1995.

[14] T. Rahajoeningroem and M. Aria, "Pada Aplikasi Filter Adaptive Noise Cancellation," Maj. Ilm. UNIKOM, vol. 11, no. 1, pp. 135-146.

[15] M. Badrul, "Optimasi Algoritma Neural Network Dengan Algoritma Genetika Dan Particle Swarm Optimization Untuk Memprediksi Hasil Pemilukada," J. Pilar Nusa Mandiri, vol. 13, no. 1, pp. 1-11, 2017.

[16] D. M. Agustina and Wijanarto, "Analisis Perbandingan Algoritma ID3 Dan C4 . 5 Untuk Klasifikasi Penerima Hibah Pemasangan Air Minum," J. Appl. Intell. Syst., vol. 1, no. 3, pp. 234-244, 2016.

[17] Y. Marbun, N. Nikentari, and M. Bettiza, "Perbandingan Algoritma Genetika dan Particle Swarm Optimization dalam Optimasi Penjadwalan Matakuliah," Fak. Tek. Umr, pp. 1-7, 2013. 